subjects contemplated include the future of scientific research and of science in modern societies. In this field also the Institute of Intellectual Co-operation and the International Labour Office have undertaken an inquiry into the social consequences of progress in mechanization, and its effects on man and the circumstances in which he lives. Discussions on the main international systems governing authors' rights have led the Committee to conclude that amalgamation of the Berne Convention and the PanAmerican Convention of Havana is not possible, and a new convention is being prepared with the object of reconciling the principles common to these Conventions and capable of forming the basis of a universal system of authors' rights.

\section{Indian Science Abstracts}

THE immense volume of original work now published necessitates a very complete system of abstracts, and the requirements of the individual sciences are now well served in this respect. Rarely, however, is an attempt made to abstract separately the scientific publications of any country, so that it is not possible to estimate its direct contributions to knowledge. Prior to the Great War, the now defunct Board of Scientific Advice published annually a résumé of the principal Indian scientific memoirs, and now, after the lapse of many years, the National Institute of Sciences in India has undertaken the much more difficult task of compiling an annual bibliography of science in India. This comprises not only the titles of all papers published by authors resident in India and of Indians working abroad, but also of papers dealing with problems specifically related to India. In the majority of cases, not only is the title of the paper given, but it is also followed by a brief, but adequate, abstract. To those who look upon India as a backward country this publica. tion will come as a revelation, not merely from the volume of the work produced but also by the high standard to which much of it attains. In a country so predominantly agricultural it is gratifying to find that so much attention is being paid to biological subjects ; nearly one half of the abstracts come under the heads of botany, zoology and physiology, the latter including veterinary and medical subjects. As the general editor points out in his introduction, the present division of subjects, which is under nine main heads, is purely tentative and may require revision in the light of experience.

Future historians of science are sure to find this publication invaluable, but we would suggest that the addition of an author index would facilitate reference. To the general editor, Dr. Baini Prashad. and to his associate editors, we would offer our congratulations, and we trust that the favourable reception which is sure to be accorded to these abstracts will encourage them to continue the issue of the bibliography. Further evidence of the great attention now being devoted to research in India is found also in the publication by the Inter-University Board, India, of a bibliography of the theses accepted for higher degrees in arts and science by the univer. sities during the years 1930-35. By their system of external examiners, the Indian universities ensure that their higher degrees shall equal those of the Western universities, and this bibliography shows how active these young universities are as centres for the advancement of knowledge. It will go far to dispel the idea that they are merely examining bodies.

\section{Post Office Tests of Inoculation against Colds}

THE common catarrhal cold is responsible for much sickness disability, and preventive vaccines containing a mixture of the predominant microbes present in the secretions have been employed, the microbes being bacteria such as $M$. catarrhalis, B. hofmanni, Friedlander's bacillus, Pneumococcus, Staphylococcus and Streptococcus. Trials of such a vaccine in the past, some of them on a large scale, have been disappointing, occasionally seeming to be useful in individual cases, but not significantly so in any large groups. A further test by the Chief Medical Officer of the Post Office during the last three years upon a large scale has, it is announced, similarly been disappointing. Volunteers were invited from large towns, and some hundreds of them were inoculated in the autumn of the three years 1933-35, and their sickness rates over periods antedating the inoculations and during the treatment were compared. Comparisons were also made with large control groups in each place of uninoculated workers. About ten per cent of the volunteers-less than half the original number-who persisted throughout the three years of the experiment showed some improvement, but taken as a whole the results were not encouraging, for there was little reduction of sickness among the whole group compared with the control groups or with their previous record. The use of anti-catarrhal vaccine as a large-scale routine measure in the future is, therefore, not considered justifiable. The negative character of the results of this experiment is not unexpected, as the common cold is now regarded as being a virus disease, the bacterial organisms associated with it being of the nature of secondary invaders.

\section{Civilization since James Watt}

AT a dinner given by the Franklin Institute on January 21, 1936, to celebrate the two hundredth anniversary of the birth of James Watt, J. P. Boyd gave a thoughtful address, a résumé of which appears in the Journal of the Franklin Institute for September. He pointed out that while James Watt was still an infant, Saint-Pièrre had suggested that the attain. ment of knowledge and the subjugation of the material world to the requirements of human welfare would lead to a continual improvement in the lot of mankind. But the logic of academicians and the pamphleteering of philosophers could not compare in effectiveness with the work initiated by James Watt. The steam engine meant freedom from the limitations of time and space. England in 1750 contained seven million inhabitants, and was over.

\section{(Continued on p. 925.)}

